\title{
Ceramic Designers' Contemporary Visions: The Contributions of Art Schools
}

\author{
Badar Almamari \\ Department of Art Education, College of Education, Sultan Qaboos University, Muscat, Oman \\ Email: badaralmamari@hotmail.com
}

How to cite this paper: Almamari, B. (2017). Ceramic Designers' Contemporary Visions: The Contributions of Art Schools. Art and Design Review, 5, 141-151. https://doi.org/10.4236/adr.2017.53011

Received: May 2, 2017

Accepted: June 11, 2017

Published: June 14, 2017

Copyright $\odot 2017$ by author and Scientific Research Publishing Inc. This work is licensed under the Creative Commons Attribution International License (CC BY 4.0).

http://creativecommons.org/licenses/by/4.0/

\begin{abstract}
In Angela Dumas' terms (2000), design must be understood as a word that describes both a process and an outcome. Most people are creative, and consequently are able to contribute to product design. However, differences in thinking styles can significantly affect the areas where art school designers can contribute most comfortably. This paper will concentrate on modern ceramic design, considering artists' thoughts about the ceramics industry and their functional and aesthetic consequences. The researcher will review different design approaches around the world, as well as various ceramics design methodologies used in art schools, and will support each case with a practical example from the field.
\end{abstract}

\section{Keywords}

Ceramic, Design, Art Schools

\section{Introduction}

Long ago, ceramic factories and designers worked together in the same place, which was made possible by the simplicity of both the designs and the manufacturing equipment. Today, design firms and ceramics factories are separate facilities, largely due to the complexity of the designing process.

Before considering ceramics design, we must outline "thinking theories, types, and styles". Some design studies follow behaviourist theorists, such as Thorndike (1911), who asserts that "human intelligence comprises only one basic process: the formation of association" (Lane, 1998). Ceramicists in other design schools adopt ideas from the Gestalt school of psychology, which established a tradition of studying problem-solving which is continued today by some theorists. Today, ceramics design is not associated with any one particular school of thought, but many designers collect thoughts and organize them to create novel designs. 


\section{Ceramics Designers' Ways of Thinking}

\subsection{Problem-Solving}

For modern ceramics designers, strategizing and problem-solving involves finding a balance of aesthetic and functional attributes, using both "imaginative thoughts" and "rational thoughts". Imaginative thought involves an artistic type of creating, whereby the designer follows his self-motivation to achieve an aesthetic purpose. On the other hand, ceramic designers are also responsible for ensuring their work is functional, solving design problems and making them relevant to real-world consumer markets. George Watson's ceramic toaster (Figure 1) combines aesthetic and functional factors, creating a product that is attractive to consumers, both useful and beautifully designed (Dean, 2012). Watson notes that the toaster is "designed to engage the user, re-invigorating the social context of toasting by questioning everything about what we toast with today".

\subsection{Productive Thinking}

Ceramic design is located under Wertheimer's (1959) umbrella of "productive thinking" (Mills, 2011). For ceramicists, researchers found this notion very workable, as "designers must consciously direct their thought processes towards a particular specified end". At the Royal College of Art, Anna Usborne and Victoria Rothschild investigated ceramic and concrete tiles; their final designs suggest a concentration on certain limitations, such as the contrast between glossy ceramic and gritty cement, and the softness and whiteness of glass against the darkness of concrete (Figure 2). Finally, their results were easy to classify in purpose and category.

\subsection{H-Creativity and P-Creativity}

Before beginning the design process, ceramics designers should decide which type of creativity would best suit their projects. In Boden's (1990) terms, creativ-

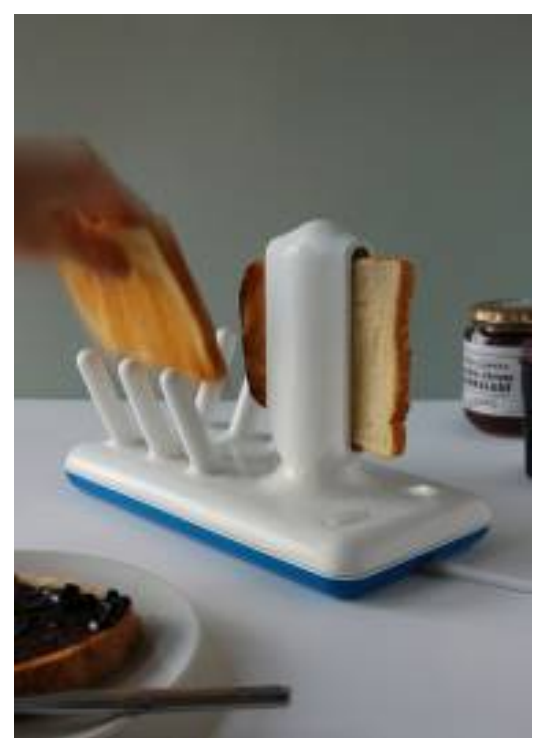

Figure 1. George Watson's ceramic toaster. 


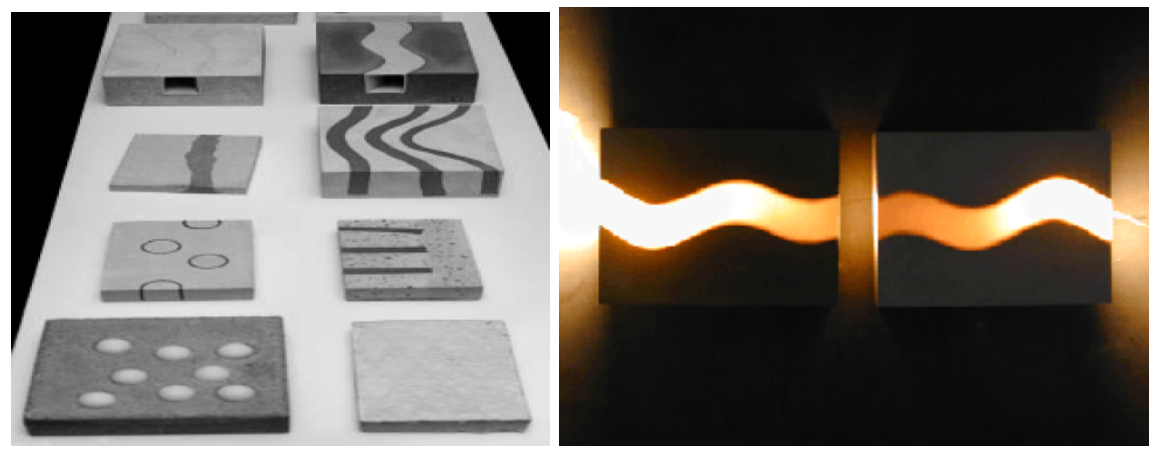

Figure 2. Anna Usborne and Victoria Rothschild ceramic and concrete tiles.

ity may be divided into high creativity (H-creativity) and psychological creativity (P-creativity). When ceramics designers create projects using $\mathrm{H}$-creativity, they aim to compete with one other, producing novel work based on fundamentally new ideas. Designers whose work reflects P-creativity tend to focus on borrowing ideas from one ceramics sector and applying them to another. Historically, this approach became widespread in different tableware workshops and factories, such as Wedgewood and Royal Dalton in England.

\subsection{Importance of Experimentation}

Thomas Edison famously noted that "genius is one percent inspiration and ninety-nine percent perspiration", illustrating the importance of experimentation and the fact that hard work is more likely to lead to solutions than waiting for a "sudden unexpected emergence of ideas". To this end, ceramicists should follow Keller's Five Phases of the Creative Process, diagrammed below (Figure 3):

Another factor relevant to designing ceramic objects is the designer's feeling about the limitations of creativity. The designer must be ambitious in all designing phases, to some extent able to ignore and supersede the challenges associated with a given project. Author Bryan Lawson (2006) has noted that "an engineering lecturer once told me that he enjoyed teaching undergraduates because they didn't know certain things were difficulties".

\subsection{Cooperation between Designers, Clients and End-Users}

One of the most important principles of ceramic object design is communication between designers, clients, and end users (Rich, 2000). "If a designer is lucky, the client will express a single clear view on all matters to the brief...users, however, are all different and likely to make differing demands on the final design". Many illustrations today represent this type of cooperation around the world, such as the mass-produced ceramic tableware designed by Harold Holdcroft, produced by Royal Dalton's factory, and processed by the Engineering and Physical Science Research Council (Figure 4).

\subsection{Heuristic Strategies}

Heuristic strategies in the design process provide another approach to solving 


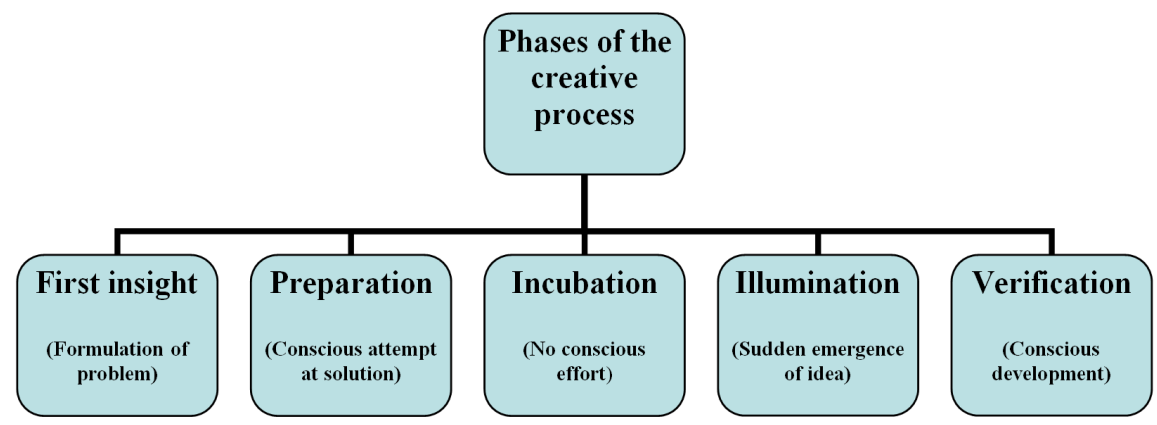

Figure 3. Keller's five phases of the creative process.

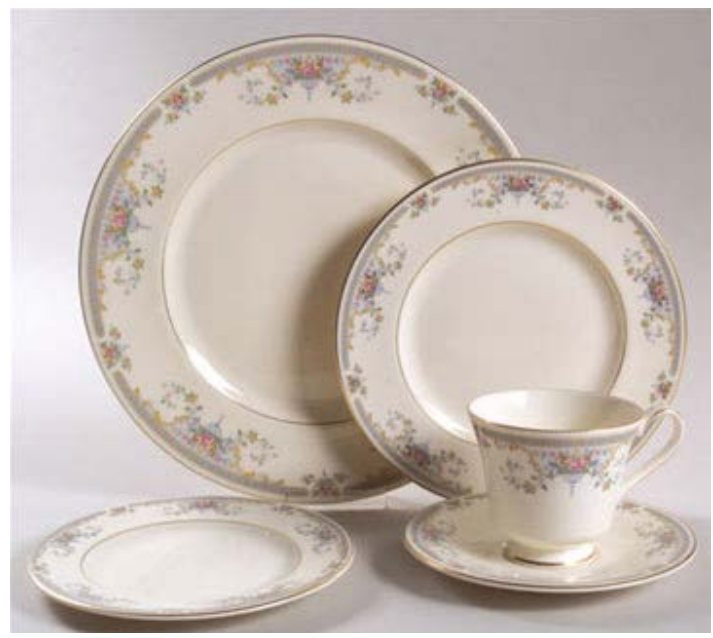

Figure 4. Harold Holdcroft, ceramics by Royal Dalton.

problems for designers. As a rule, designers solve problems only when they investigate all solutions, including weaker ones. The essence of this approach is simultaneously educational and solution-oriented: "the central idea" in the designer's mind should be enriched through all phases of the designing process. Some believe, for example, that ceramic design should focus on filling an aesthetic gap, rather than on solving industrial and technological problems. The designer should decide the central purpose of the project by considering whether the project is intended to be aesthetic, functional, or both.

\subsection{Vertical Thinking}

In Even Edward de Bono's terms, ceramic design today is classified as "vertical thinking", whereby the designer must dig deeper and bigger holes rather than digging many holes. In other words, design should be investigated deeply, rather than the process de Bono described as "lateral thinking", exemplified by designers who change their lines of thought easily, moving from one idea to another.

\subsection{Telling Stories}

In recent years, some ceramic designers have begun to support their work with stories; this approach has become widespread in design schools throughout the world. Some scholars believe that this technique is not so much about explaining 
the design as it is about advertising the product. The "telling a story" tactic is another way to study end-users' behaviours and interactions with these objects, specifically describing the users' feelings while using that object. For example, designers Xinhe Jiang and Zhuo Wang explain that their "Parlez Avec Moi" breakfast tableware "leaves you no more lonely breakfast (Figure 5). Breakfast contains the love from our mother, lover or children...with 'Parlez Avec Moi', breakfast can be a way to express these loves. We try to make the plates service like an intermedia in the family".

\subsection{Computer Programs as Designers}

Controversially, computer programs are sometimes used today to create ceramic designs (Figure 6). Personally, I agree with Lawson's (2006) assertion that what some designers call "computer-aided design" is actually "computer-aided drawing". Lawson also notes that "many well-known and successful designers have articulated their opposition to using computers in their design process". One of the problems with much computer software in general, and CAD software in particular, is the ways in which the conversation must be on the computer's terms rather than the human designer's terms (Pipes, 2007).

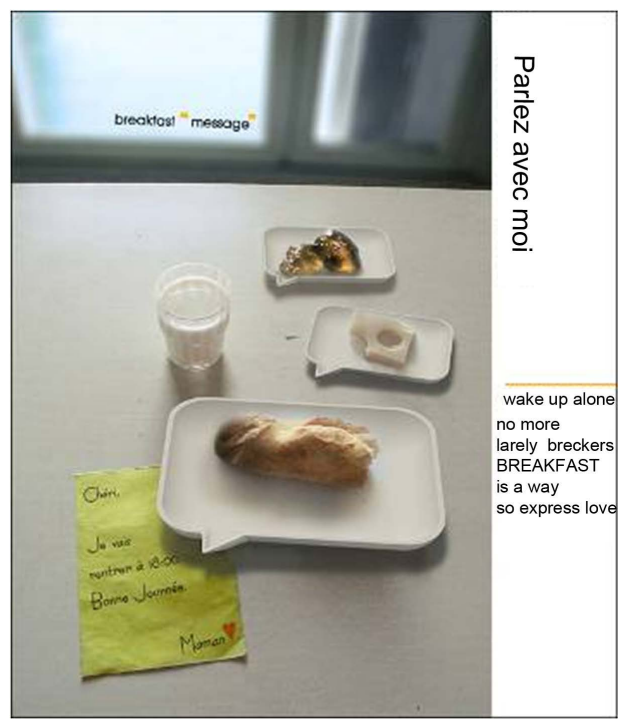

Figure 5. Xinhe Jiang and Zhuo Wang's "Parlez avec moi" breakfast tableware.

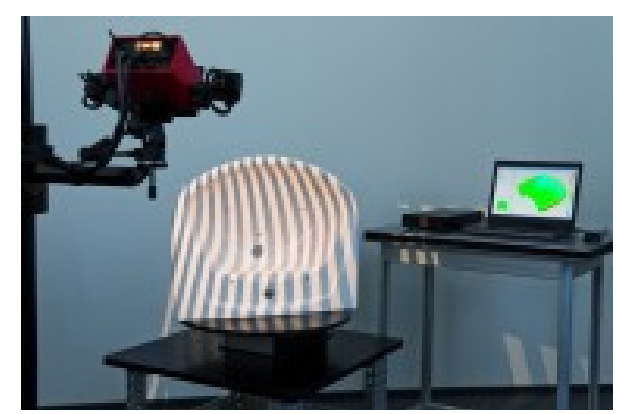

Figure 6. Ceramics CAD software. 


\subsection{Durability}

For designers, ceramics provide a platform to create alternatives to classic items that humans have used for a long time (Piepenburg, 2012). This suggest the need for ceramic science to keep up with the design stage. In 2008, faux coal for use in the home was replaced by innovative ceramic coal, called "Fire Jacks", which is both cleaner and more practical (Figure 7). The designer worked hard to provide the user with beautiful white coal, rather than the black which existed for its functional purpose.

\subsection{Material Challenges}

Both designers and ceramics engineers must challenge the ceramic material to achieve the best possible results. This task requires both sides to share their knowledge, collaborating to use clay and decorative materials without limits. The Droog design group has launched an innovative project called "Challenging Porcelain Elegance and Smoothness" in cooperation with "Rosenthal" (Figure 8). The project sought to increase competition with other porcelain producers by examining the limitations of porcelain as a material for tableware objects, deeply investigating not only porcelain formation, but also decorative techniques and colouring

\subsection{Multiple Uses}

Widely used design ideas should exist like archive in designers' minds, available
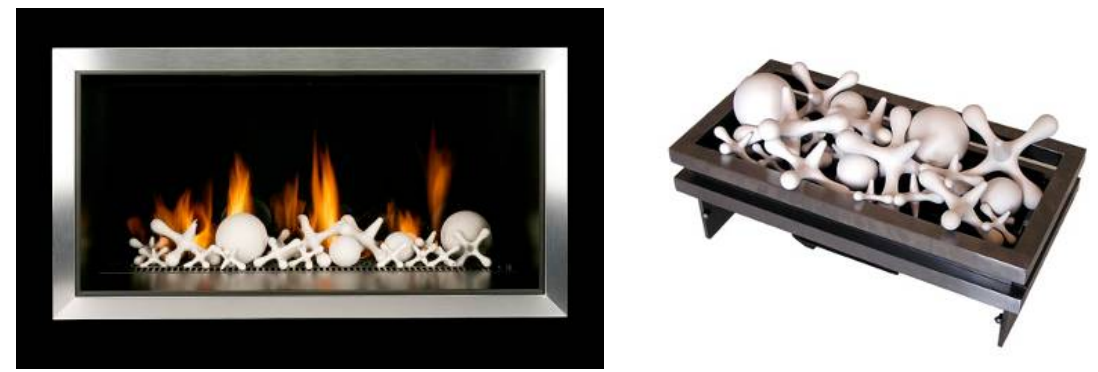

Figure 7. Fire Jacks ceramics.

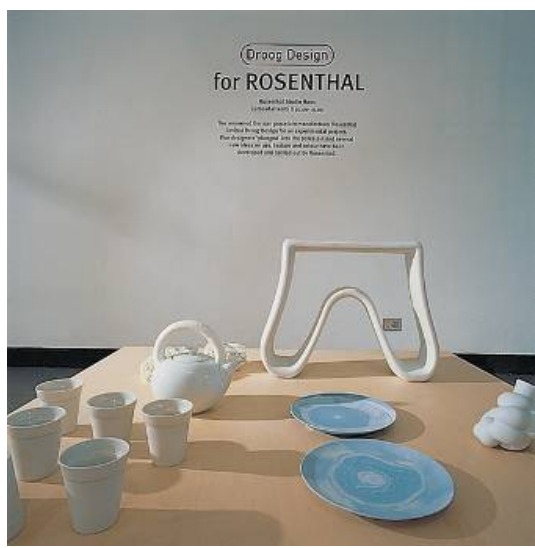

Figure 8. Challenging Porcelain Elegance and Smoothness project in cooperation with "Rosenthal". 
for use at any time and in any phase of planned projects. Simultaneously, however, the designer is responsible for re-using them in different forms and for different purposes. To illustrate this, consider the jigsaw puzzle, a shape used in many ceramic and industrial design projects (Figure 9). However, producer Norcroft China and prototype C.P. Ceramics have created an extraordinary table-top oil-lamp using a jigsaw puzzle form.

\subsection{Pottery Legacy}

Ceramics designers are surrounded by the historical legacy of pottery craft, and often emphasise the influence of old designs on contemporary ones; as David Queensberry explains, "We are working within the traditions of the oldest craft, of which we have a continuous record". Many ceramic designers are attracted by nostalgia, developing contemporary designs that reveal the influences of the past, and of people's classic lifestyles over the years (Quinn, 2007). As one of the best design firms in Europe, Queensberry Hunt has investigated this vision through their ceramic designs, with manufacturing support from Fratelliguzzini (Figure 10). For example, their tableware set, "Feeling", resulted from a new investigation into prehistoric designs from the 3rd millennium BC. Queensberry connects this design with its historical origins when he says that "As designers working in the twenty-first century, we are influenced by the trends and fashions of our time, but we are also respectful of the long history of our subject".

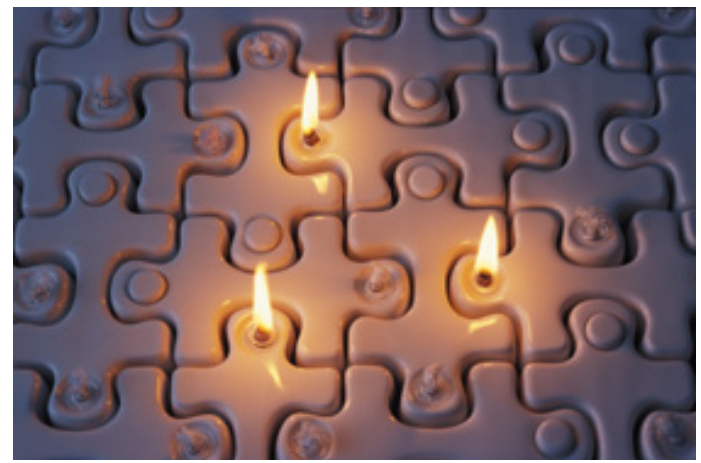

Figure 9. Jigsaw puzzle by Norcroft China and prototype C.P. Ceramics.

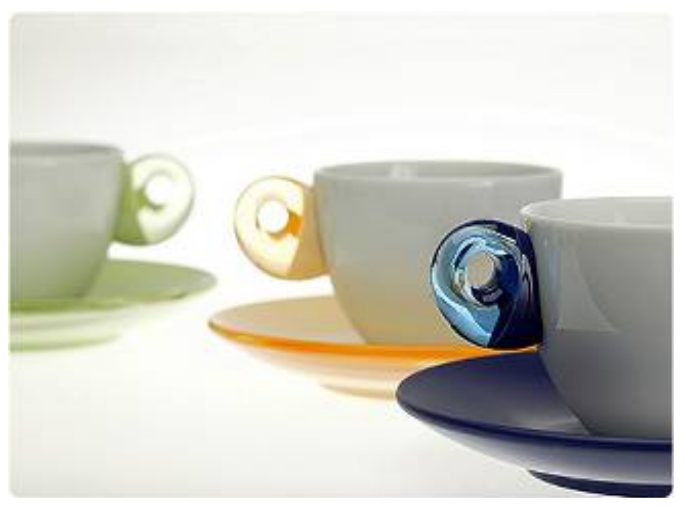

Figure 10. Queensberry Hunt from Fratelliguzzini. 


\subsection{Back to Old Techniques}

In addition to older designs, old manufacturing techniques are also used in modern companies. For example, the Wade ceramic factory has recently used the "jiggering and jolleying" technique to produce white tableware, while other competitors use injection and moulds, which are less costly, as well as prototypes. The "jiggered" pots are very popular with consumers, appearing less distorted and commercial than moulded tableware. Many of these types of ceramics are designed for limited production for special customers, so the factory focuses on design and precision more than on mass production.

\subsection{Mass Production}

On the other hand, the relatively recent development of Viscous Plastic Processing (VPP) technology has become the best way to satisfy market demands. This type of ceramic production began as a collaboration between three corporations, designed by Harold Holdcroft, produced by Royal Dalton, processed by the Engineering and Physical Science Research Council (Figure 11). Beginning in 1962, this technology allowed Royal Dalton to produce the most successful ceramic range of all time, selling more than 100 million pieces.

\subsection{Sustainability}

Sustainable design has become important in all design fields, and ceramics are some of the most ecologically sound materials, both chemically and physically. In an article titled "Humane and Sustainable Design is Still Complex, ceramics designer Satyendra Pakhalé writes that "craftsmanship is the primary requirement for a good industrial design, not a romantic style instrument (Figure 12). If things go as they should, suitable technology and choice of materials will result in sustainable products".

\subsection{Inspiration by Daily Visual Observations}

"Daily visual observations" are considered a resource for inspiration, and can be influential for ceramics designers due to their daily interactions with used objects such as tableware and sanitary engineering. This has led designers to elevate
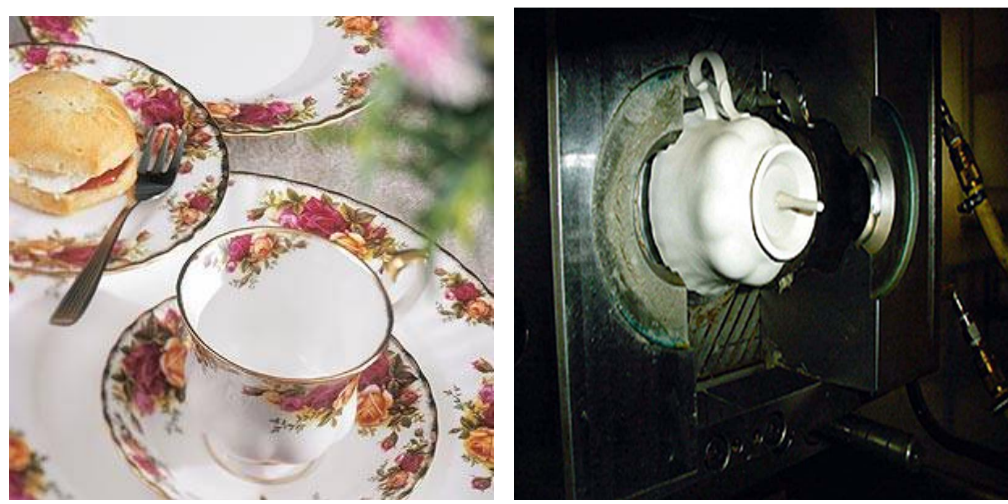

Figure 11. Ceramic tableware designed by Harold Holdcroft, (Royal Dalton). 

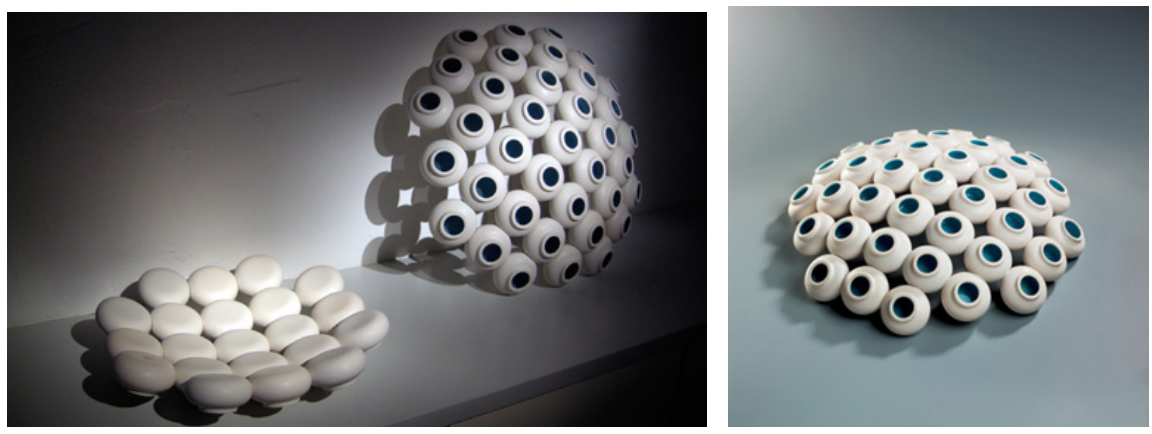

Figure 12. Humane and sustainable design by Satyendra Pakhalé.

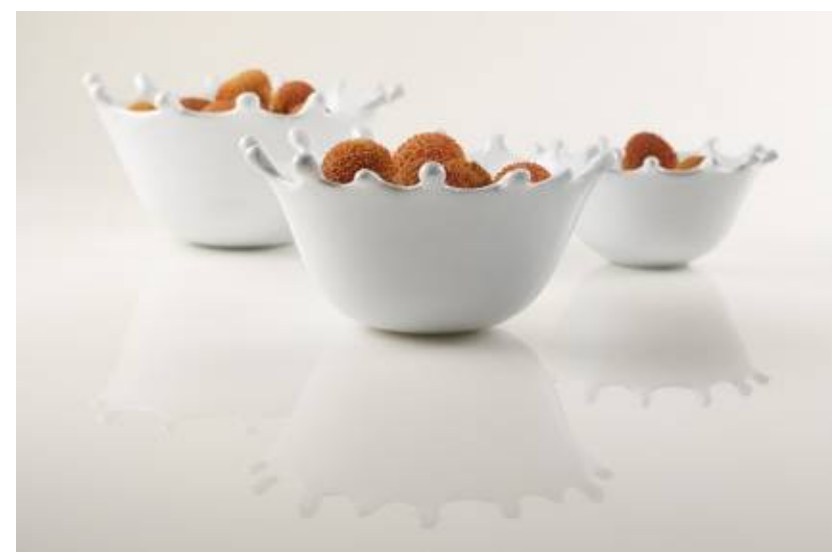

Figure 13. "Milk Moments" by Laura Strasser \& Milia Seyppel.

producers of novel designs to the ranks of those who have created classical designs. "Milk Moments" is a bowl designed by a study group including Laura Strasser \& Milia Seyppel (Figure 13). The design concept is inspired by the breakfast experience, and the container created is to be used for corn flakes at breakfast as well.

\subsection{Brand Issue}

Brand reputation is important in all areas of lifestyle and domestic product design, but especially so in the field of ceramics. This has driven ceramic developers to advertise their names before their products. For example, Wedgwood-the biggest name in English ceramic tableware, established 250 years ago-has nonetheless declined and suffered after transferring their business to Indonesia in pursuit of cheap labour. Japanese-born ceramic artist Kaoru Parry has asserted that "Japanese people loved Wedgwood, but they wouldn't buy it unless it was made in England".

\subsection{Hygienic Issue}

Hygienic use, one of a number of "social design issues", is another ceramic design matter in this era. In fact, in the past several years, some design competitions have focused only on hygienic issues. As a natural materials, ceramics have won the competition over other product materials such as plastic and metal, and 
this is particularly clear in food tableware and sanitary ware (Waal, 2003). Moreover, ceramics designers can further promote the ceramic industry's suitability to hygienic products by investigating human behaviour surrounding those products' daily physical use. For example, KC LO's "Polar Molar" is a table-top toothpick holder made in cast glazed studio pottery ceramic, and was developed after an investigation of human behaviour in relation to toothpick use after meals (Figure 14).

\subsection{Beyond Tableware}

The last decade has seen the development of the "micro ceramic" industry, possibly because of its characteristics to be used instead of other materials in design field. Clays, glazes, and firing processes have their superiority in specialized or "micro" industries such as watches and spacecraft. For example, Radio ceramic watches, were previously developed to be scratch-proof-that is, functional-but the latest generation has added an aesthetic dimension, namely the users' feeling of polished and matte finishes, as well as bio inertness. Ceramics has demonstrated its superiority for the watch industry, able to provide these experiences using only low-cost and practical materials.

\subsection{Alternative Materials}

If ceramics designers concentrate on ceramic materials and their possibilities in terms of form and decoration alone, they may find other mediums confusing, such as cement, considered an effective member of the construction family. Willy Guhl's 1954 cement chair design reminds us that materials like cement can be an alternative to ceramic material in terms of form (Figure 15). This innovative design was further developed by different designers as a result of its success in the market (Lefteri et al., 2003).

\section{Conclusion}

In this paper, the researcher reviewed various ceramic design tactics in educational levels, along with the most important methodologies of ceramics design used in art schools, and supported each case with practical examples from the

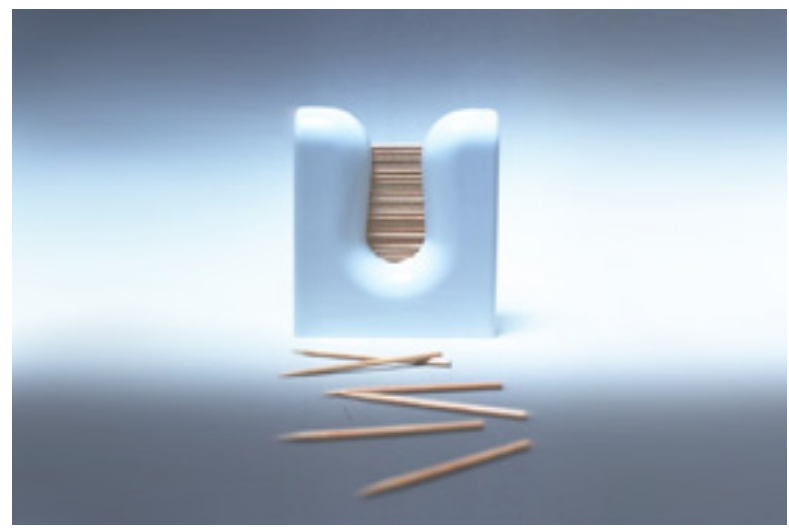

Figure 14. KC LO’s “Polar Molar” table-top toothpick holder. 


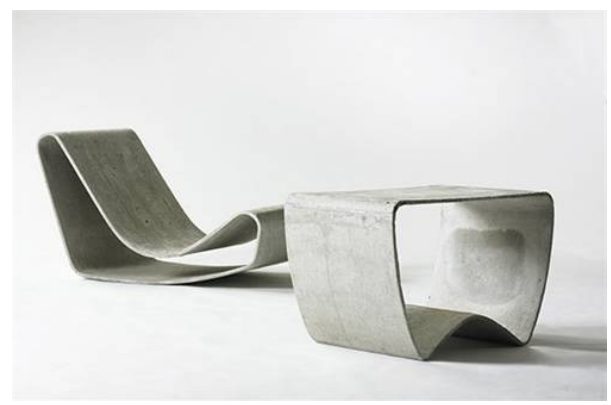

Figure 15. Cement chair by Willy Guhl (1954).

field. This paper has given an account of the widespread use of both contemporary and traditional technologies used in ceramic design, demonstrating that the possibilities within this field are nearly unlimited.

\section{References}

Dean, S. (2012). What Does Elephant Taste Like?: The Ceramic Glide Toaster. http://www.bonappetit.com/uncategorized/article/what-does-elephant-taste-like-the-ce ramic-glide-toaster

Dumas, A. (2000). Theory and Practice of Industrial Design. http://www.adi.pt/docs/innoregio_theor_design.pdf

Lane, P. (1998). Ceramic form Design and Decoration. London: A\&C Black.

Lawson, B. (2006). How Designers Think: The Design Process Demystified. London: Routledge, Taylor \& Francis Group.

Lefteri, C., Emerson, Z., \& Rashid, K. (2003). Ceramics: Materials for Inspirational Design. Hove: RotoVision.

Mills, M. (2011). Surface Design for Ceramics. New York: Lark Crafts.

Piepenburg, R. (2012). The Spirit of Ceramic Design. Pebble Press.

Pipes, A. (2007). Drawing for Designers. London: Laurence King.

Quinn, A. (2007). Ceramic Design Course: Principles, Practice, and Techniques: A Complete Course for Ceramicists. Hauppauge, NY: Barrons Educational Series.

Rich, C. (2000). The Ceramic Design Book: A Gallery of Contemporary Work. Asheville, NC: Lark.

Waal, E. D. (2003). Design Sourcebook: Ceramics. London: New Holland. 
Submit or recommend next manuscript to SCIRP and we will provide best service for you:

Accepting pre-submission inquiries through Email, Facebook, LinkedIn, Twitter, etc. A wide selection of journals (inclusive of 9 subjects, more than 200 journals)

Providing 24-hour high-quality service

User-friendly online submission system

Fair and swift peer-review system

Efficient typesetting and proofreading procedure

Display of the result of downloads and visits, as well as the number of cited articles Maximum dissemination of your research work

Submit your manuscript at: http://papersubmission.scirp.org/

Or contact adr@scirp.org 